\title{
SOSIALISASI DAN PELATIHAN PENGGUNAAN MESIN PEMECAH BUAH KAKAO DI DESA BUBAA, KECAMATAN PAGUYAMAN PANTAI
}

\author{
Sosialization And Training For use Coconut Fruit Machines In Bubba Village \\ Paguyaman Pantai District
}

\author{
Romi Djafar'), Siradjuddin Haluti' ${ }^{2)}$, Yunita Djamalu ${ }^{3)}$, Sjahril Botutihe ${ }^{4)}$ \\ $\mathbf{1}, \mathbf{2 , 3}, \mathbf{4}$, Staf Pengajar Program Studi Mesin dan Peralatan Pertanian, Politeknik Gorontalo \\ J1. Muchlis Rahim Desa Panggulo, Kec. Botupingge, Kab. Bone Bolango, Prov. Gorontalo \\ Email : romidjafar@poligon.ac.id
}

\begin{abstract}
ABSTRAK
Masyarakat desa bubaa masih menggunakan cara-cara tradisional padahal teknik pengolahan buah kakao harus diperhatikan karena sangat menentukan mutu akhir produk kakao, hal itu berkaitan dengan proses pembentukan cita rasa khas kakao dan pengurangan cita rasa kakao yang tidak dikehendaki seperti rasa pahit dan sepet. Melalui teknologi pengolahan buah kakao masyarakat dapat memperoleh buah kakao yang lebih berkualitas dengan proses pengolahan yang lebih mudah dan relatif cepat yakni dengan mesin pemecah buah kakao. Luaran dan target capaian yang diharapkan adalah adanya draft buku ajar, menjadi rekomendasi untuk menggunakan dan memanfaatkan alat TTG Pemecah buah kakao dan diharapkan terjadi peningkatan kualitas dan kesejahteraan masyarakat Desa Bubaa. Adapun metode pelaksanaan kegiatan adalah penyuluhan dan pelatihan guna memberikan informasi kepada masyarakat tentang alat dan bahan, cara kerja alat dan fungsi dari setiap komponen alat kemudian dilakukan pelatihan sekaligus demonstrasi alat dengan menggunakan 3 karung buah kakao dan melihat kinerja serta proses kerja alat pemecah buah kakao.
\end{abstract}

Kata Kunci : Kakao, TTG

\section{ABSTRACT}

The community of Bubaa still uses traditional methods even though the cocoa fruit processing technique must be considered because it greatly determines the final quality of cocoa products, it is related to the formation process of the typical cocoa flavor and the reduction of unwanted cocoa flavors such as bitter taste. Through the technology of cocoa fruit processing, the community can obtain better quality cocoa fruit with processing that is easier and relatively fast, namely with a cocoa fruit breaking machine. The expected output and target is the draft textbook, a recommendation for using and utilizing the TTG tool for cocoa fruit breaking and it is hoped that there will be an increase in the quality and welfare of the people of Bubaa Village. The method of conducting the activity was counseling and training to provide information to the community about tools and materials, how the tools and functions worked for each component of the equipment and then training and demonstration using three sacks of cocoa and seeing the performance and work process of the cocoa fruit cracker.

Keywords: Cocoa, TTG 


\section{PENDAHULUAN}

Desa Bubaa salah satunya, desa yang berada di Kecamatan Paguyaman ini memiliki luas hamparan dataran yang luas yang terdiri dari perkebunan dan sebagian besar dimanfaatkan untuk penanaman buah kakao namun dalam hal pengolahan buah kakao, masyarakat desa bubaa masih menggunakan cara-cara tradisional padahal teknik pengolahan buah kakao harus diperhatikan karena sangat menentukan mutu akhir produk kakao, hal itu berkaitan dengan proses pembentukan cita rasa khas kakao dan pengurangan cita rasa kakao yang tidak dikehendaki seperti rasa pahit dan sepet. Melalui teknologi pengolahan buah kakao masyarakat dapat memperoleh buah kakao yang lebih berkualitas dengan proses pengolahan yang lebih mudah dan relatif cepat yakni dengan mesin pemecah buah kakao.

Banyak masyarakat desa Bubaa yang membutuhkan mesin pemecah kakao untuk pengolahan kakao secara cepat dan mudah sehingga bisa meningkatkan kualitas buah kakao dan mempercepat proses pengolahannya. Adapun Manfaatnya dapat memberikan pengatahuan teknis cara pembuatan dan penggunaan mesin pemecah kakao, menumbuhkan kebersamaan masyarakat dalam meningkatkan kualitas buah kakao yang dihasilkan untuk kepentingan bersama.

\section{SOLUSI DAN TARGET LUARAN}

\section{Solusi}

a. Solusi yang diharapkan dari permasalahan diatas adalah :

1. Adanya alat TTG (Teknologi Tepat Guna) untuk mempercepat proses pemecahan kakao

2. Meningkatkan hasil prodeksi kakao

3. Higienis karena menggunakan alat TTG yang terbuat dari stainless steel.

b. Luaran dan target capaian

Jenis luaran kegiatan :
1. Draft buku ajar

2. Rekomendasi Penggunaan dan pemanfaatan alat TTG Pemecah buah kakao

3. Peningkatan kualitas dan kesejahteraan masyarakat Desa Bubaa

c. Target capaian yang akan dihasilkan:

1. Desa Bubaa akan menjadi desa percontohan didalam pengolahan buah kakao yang baik.

2. Pemerintah daerah setempat termotivasi dalam memelihara dan memanfaatkan teknologi cara pembuatan dan penggunaan mesin pemecah kakao.

3. Membangun kebersamaan warga desa dalam pembuatan alat TTG untuk proses pemecahan buah kakao

\section{METODE PELAKSANAAN}

\section{Alat dan Bahan}

Alat dan bahan yang digunakan sebagai berikut:

1. kakao

2. Plastik dan ember penampung kakao

\section{Cara Kerja Alat}

Cara kerja alat adalah sebagai berikut :

1. Siapkan buah kakao

2. Hidupkan mesin pemecah kakao

3. Masukan buah kakaoke hopper in

4. Masukan buah kakaoke hopper in

5. Buka penutup hopper in

6. Proses pemecahan kakao

7. Penyortiran hasil pecahan buah kakao (pemisahan biji dan kulit)

8. Selesai

\section{Peninjauan Lokasi}

Lokasi pengabdian mengenai pemecah dan pengering kakao akan dilakukan di desa BubaA Kecamatan Paguyaman Kabupaten Gorontalo. Desa ini banyak menghasilkan produksi buah kakao yang setelah di panen kemudian kakao di pecah 
dan dikeringkan untuk kemudian dijual kekota.

\section{Sosialisasi dan Musyawarah}

\begin{tabular}{lcr}
\multicolumn{1}{c}{ Kegiatan pelatihan } & sebelumnya \\
disosialisasikan & guna & memberikan \\
informasi awal & kepada & masyarakat \\
sehingga dalam & &
\end{tabular}
pelaksanaan nanti dapat mempersiapkan segala sesuatu yang diperlukan. Sosialisasi ini sekaligus dilakukan musyawarah bersama baik dengan masyarakat maupun apparat desa BubaA dan jajarannya. Musyawarah ini bertujuan untuk menentukan jadwal pelaksanaan kegiatan pelatihan dan menentukan materi pelatihan yang akan dilaksanakan.

\section{PELAKSANAAN KEGIATAN}

Kegiatan PKM yang dilaksanakan dengan penyuluhan dengan metode ceramah tentang tata cara pembuatan dan cara kerja dari mesin pemecah buah kakao. Dilanjutkan dengan demo alat mesin pemecah buah kakao oleh tim dengan masyarakat peserta pelatihan. Kegiatan ini dilaksanakan pada hari Senin, tanggal 19 bulan Agustus 2017 dari pukul 09.00 s.d 12.00 wita. Peserta kegiatan berjumlah 39 orang masyarakat petani kakao dan petani lainnya di Desa Bubaa Kec. Paguyaman.

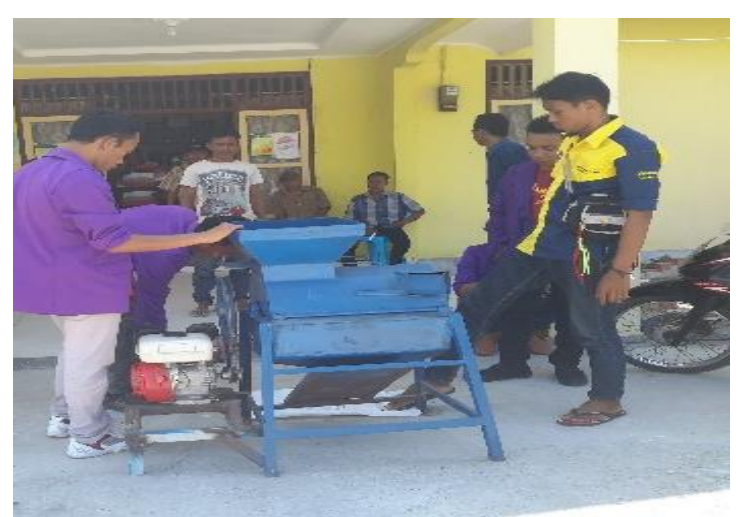

Pelaksanan kegiatan PKM ini dibagi menjadi 2 (dua) tim. Tim yang pertama bertugas sebagai penyuluh dan tim yang kedua melaksanakan demonstrasi mesin pemecah dan pengering buah kakao. Adapun teori/materi yang disampaikan saat penyuluhan yakni :
- Potensi Pengembangan buah kakao 5 tahun kedepan

- Pengolahan buah kakao

- Cara pembuatan mesin pemecah dan pengering buah kakao

- Cara kerja mesin pemecah dan pengering buah kakao

Pada demonstrasi alat, cara kerja mesin pemecah buah kakaolah yang dijelaskan oleh para demonstran. Sehingga masyarakat lebih paham dengan cara kerja mesin tersebut. saat pelaksanaan demo cara kerja mesin pemecah dan pengering buah kakao, masyarakat dibagi dalam

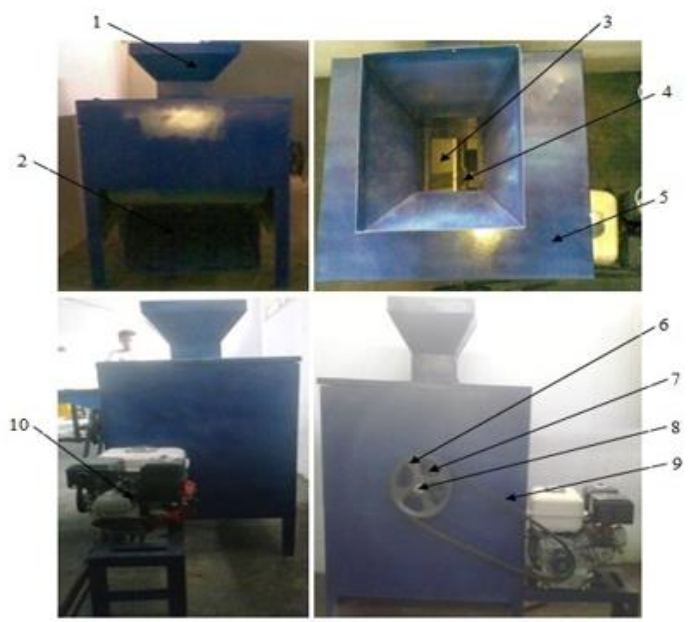

empat kelompok. Setiap satu kelompok mendapat kesempatan mendemonstrasikan mesin pemecah dan pengering buah kakao sebanyak satu kali.

Acara kemudian dilanjutkan sesi Tanya jawab. Berbagai pertanyaan diajukan secara antusias oleh para peserta dalam sesi tanya jawab.Secara garis besar inti dari pertanyaan para peserta adalah:

1. Berapa biaya pembuatan mesin pemecah buah kakao

2. Selain mesin pemecah buah kakao, mesin apalagi yang ada untuk pengolahan pasca panen hasil pertanian di Politeknik Gorontalo

3. Prospek tanaman kakao untuk kedepan

Program pengabdian kepada masyarakat berupa pelatihan cara pembuatan dan cara kerja mesin pemecah 
dan pengering buah kakao yang sudah dilaksanakan ini diharapkan dapat menambah pengetahuan dan ketrampilan peserta tentang cara kerja/penggunaan mesin pemecah dan pengering buah kakao. Selain itu dari kegiatan ini diharapkan peserta mendapatkan solusi dalam pengolahan/pemecahan buah kakao, sehingga para petani kakao lebih lebih efektif dari segi waktu dalam memecahkan buah kakao.

\section{HASIL DAN PEMBAHASAN}

Hasil kegiatan PkM secara garis besar mencakup beberapa komponen sebagai berikut:

1. Keberhasilan target jumlah peserta pelatihan

2. Ketercapaian tujuan pelatihan

3. Ketercapaian target pelatihan yang telah direncanakan

4. Kemampuan peserta dalam mendemonstrasikan mesin pemecah dan pengering buah kakao

Target peserta telah memenuhi yang telah direncanakan sebelumnya. target demo alat mesin secara umum sudah baik, namun karena keterbatasan jumlah alat dan waktu pelaksanaan maka peserta tidak dapat mempraktekkan penggunaan alat dalam waktu yang lama karena alat harus segera dirolling ke kelompok lainnya.

Namun secara umum peserta sudah bisa menguasai cara mengoperasikan mesin pemecah dan pengering buah kakao. Ketercapaian target pelatihan pada kegiatan PkM ini sudah cukup baik. karena pada materi telah dapat disampaikan secara keseluruhan.Masing-masing kelompok membagi tugas kepada anggota untuk mengambil bagian pada saat giliran kelompokna untuk mendemokan mesin pemecah dan pengering buah kakao. Ada yang dibagian hopper menuangkan kakao utuh kedalam mesin, ada bagian yang mengumpulkan hasil dari mesin pemecah, ada yang dibagian operator mesinnya.
Sehingga demonstrasi mesin berjalan dengan lancar.

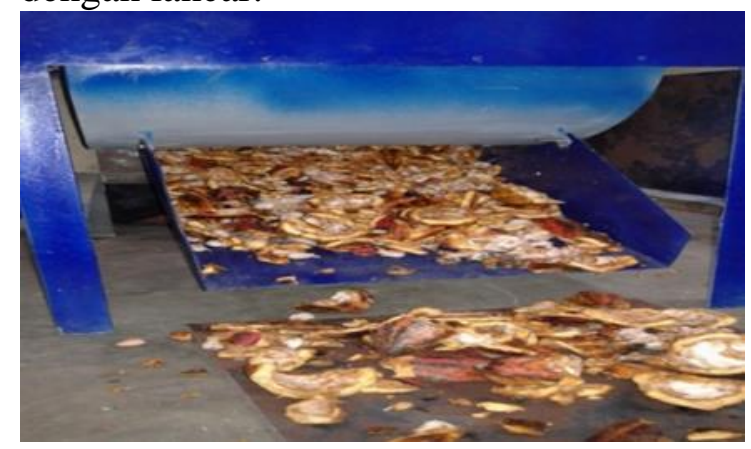

Diharapkan setelah pelatihan ini para peserta akan menggunakan mesin ini untuk memecahkan buah kakao saat pengolalahan hasil panen kakao, sehingga pengolahan kakao lebih efisien dari segi waktu.

\section{DAFTAR PUSTAKA}

Amin Sarmedi. 1997. Penelitian Pengeringan Biji Kakao dan Penerapannya. Majalah BPP Teknologi, No; LXXX/Agustus '97

Direktorat Jenderal Perkebunan. 2009. Buku Panduan Teknis Budidaya Tanaman Kakao (Theobroma cacao L.). Jakarta

J. Spillane, James Dr. 1995. Komoditi Kakao (Peranannya dalam Perekonomian) Kanisius. Yogyakarta

Pusat Penelitian Kopi dan Kakako Indonesia. 2004. Panduan Lengkap Budidaya Kakao. Agromedia Pustaka. Jember

Susanto, F. X. Ir. 1994. Tanaman Kakao. Cetakan Pertama. Kanisius. Yogyakarta

Wahyudi, T., T.R Pangabean., dan Pujianto. 2008. Panduan Lengkap Kakao Manajemen Agribisnis dari Hulu hinggaHilir. Penerbit Swadaya. Jakarta 